\title{
Bone Mineral Content in a Sample of Indonesian Population
}

\author{
Iwan Ekayuda, Sri Pardiastuti Bhudjono*, Pandu Riono**
}

\begin{abstract}
Abstrak
Telah dilakukan pemeriksaan CT QCT (Quantitative Computed Tomography) pada 223 subjek penelitian yang terdiri dari 164 wanita (rata-rata umur 38,84 tahun) dan 59 pria (rata-rata umur 43 tahun) yang sehat dengan menggunakan pesawat CT-Scan Somatom - CR (Siemens AG, Erlangen Germany). Digunakan fantom kalibrasi dari Siemens yang terdiri atas 2 komponen yaitu air dan $200 \mathrm{mg} / \mathrm{ml}$ Hydroxyapatite. Beberapa kesimpulan yang didapat adalah:laju penurunan kandungan mineral tulang menurut umur pada subjek wanita tidak berjalan homogen, yaitu terjadi percepatan penurunan pada masa peri-menopause; laju penurunan kandungan mineral tulang menurut umur pada subjek pria berjalan homogen; nilai kandungan minneral tulang rata-rata pada pria Indonesia pada berbagai kelompok umur tidak jauh berbeda dengan penelitian-penelitian di mancanegara sedangkan pada wanita umur 50 tahun juga tidak jauh berbeda, setelah periode umur tersebut menunjukkan adanya perbedaan; dan nilai rata-rata kandungan mineral tulang menurut umur pada kelompok pria dan wanita berdasarkan model regresi yang sesuai dapat dipertimbangkan sebagai nilai-nilai acuan di Indonesia.
\end{abstract}

\begin{abstract}
Quantitative Computed Tomography (QCT) was performed on 223 healthy subjects, consisting of 164 females (average age 38.84 years) and 59 males (average age 43 years), using a Somatom - CR CT-Scanner (Siemens AG, Erlangen, Germany). A Siemens calibration phantom, which is composed of 2 components, water and $200 \mathrm{mg} / \mathrm{ml}$ hydroxyapatite, was used. The rate of BMC reduction with age in the female subjects was found to be not uniform. There was accelerated reduction during the perimenopausal period. This rate of reduction was found to be uniform in the male subjects. The average BMC of these male Indonesian in the various age groups did not differ greatly from reference values of other countries, as was also found in the female Indonesian subject up to the age of 50. There was a marked disparity from other studies in women over 50. Using the appropriate regression model, these values can be considered as reference values for Indonesians.
\end{abstract}

Keywords : Quantitarive Computed Tomography, bone mineral content, osteoporosis

\section{INTRODUCTION}

Excessive loss of bone mass, or osteoporosis, leads to an increased risk of fractures from minimal trauma. Osteoporosis will become a major health problem in Indonesia as the number of elderly people in the population increases, the result of a demographic transitional process. In developed countries such as the United States, osteoporosis is considered to be the cause of 1.2 million fractures each year in postmenopausal women. ${ }^{1}$ It is estimated that in the United States, $25 \%$ of the women over the age of 60 suffer from one or more vertebral fractures caused by osteoporosis. $^{2}$
There are 2 types of osteoporosis, primary and secondary osteoporosis. Primary osteoporosis is associated with advancing age, and is usually found in postmenopausal women and elderly men. Secondary osteoporosis is related to certain diseases, the use of corticosteroids, or prolonged immobilization.

Osteoporosis usually does not give symptoms until fracture occurs. Although bone biopsy is the most accurate quantitative analysis method of determining the mineral content, it is not routinely performed because it is invasive and difficult. With advanced imaging techniques, such as Quantitative Computed Tomography (QCT), it is possible to diagnose the disease by examining the BMC with high precision and

Department of Radiology. Faculty of Medicine, University of Indonesia, Jakarta, Indonesia

* Radiology Unit, St. Carolus Hospiral, Jakarta, Indonesia

** Health Research Center, Research Institute, University of Indonesia, Jakarta, Indonesia 
accuracy. This technique is also simple, noninvasive, relatively inexpensive, and needs only about $10-15$ minutes to perform.

QCT is considered to be accurate in the early detection of bone mineral loss. ${ }^{2-9}$ Early changes can be detected in the vertebral trabecular bone, which has a turn-over rate of about 8 times than cortical bone. ${ }^{2}$ This is because the vertebral bodies is made up of $75 \%$ trabecular bone. QCT can measure the mineral content of trabecular bone selectively, without superposition of the cortical bone or other tissues. By carefully choosing the exact site and directly measuring the bone density with QCT, it is possible to minimize analytical errors caused by cortical bone, osteophytes, sclerosis, and calcification.Bone mineral analysis of the extremities does not reflect the mineral content of the axial skeleton such as the vertebrae. ${ }^{2}$

There has not been many studies on osteoporosis in Indonesia at this time. The average BMC values of Indonesian and the pattern of decline with age in men and women are also not fully known. The results of this study will be of importance to other investigators of osteoporosis, since it is hoped that reference values will be obtained for various age groups of both men and women.

The aim of this study is to investigate the average BMC and the pattern of change on a sample of Indonesian population of different age and sex. Comparisons will also be made on the Indonesian pattern of change to those reported by other studies.

\section{MATERIALS AND METHODS}

\section{Selection of subjects}

This is a cross-sectional study and the subjects were selected from a healthy population members of the Program Jaminan Pemeliharaan Kesehatan (PJPK), a health insurance program of the St. Carolus Hospital, Jakarta, in a random proportional method. Those selected underwent a medical examination. The exclusion criteria were :

- Prolonged immobilization, of at least 2 weeks for the past few months.

- Receiving steroids, anticonvulsants, anticoagulants, furosemide, or heparin.

- Receiving hormonal therapy, including contraceptives.

Conditions such as hypogonadism, menstrual irregularities, galactorrhoea, premature menopause, or other hormonal abnormalities.

- Malignancies.

- Malabsorption syndrome.
- Postovariectomy.

- A history of fracture of the femur or vertebra.

- Smokers or heavy drinkers.

- Pregnancy.

There were 223 subjects selected from March to October 1993. They consisted of 164 females and 59 males. The average age of the males was 43 years (SD 13.16), with the youngest 21 and the oldest 73 . The females had an average age of 38.84 years (SD 12.92), ranging from 20 to 75 .

Table 1. Distribution of age group according to sex

\begin{tabular}{ccc}
\hline Age group (yr) & Female & Male \\
\hline $20-30$ & 48 & 10 \\
$31-40$ & 60 & 20 \\
$41-50$ & 25 & 9 \\
$51-60$ & 16 & 12 \\
$61-$ & 15 & 8 \\
\hline
\end{tabular}

The female subjects comprised of Indonesians from various ethnic groups, such as Javanese, Sundanese, Betawis, Bataks, Flores, Balinese, Minangs, Timorese, Palembangs, or of mixed parentage and Chinese. The majority were Javanese $(50 \%)$, Sundanese $(18.9 \%)$, and Chinese $(8.5 \%)$. The male subjects also were Indonesians of various ethnic groups, such as Javanese, Sundanese, Betawis, Bataks, Flores, Balinese, Timorese, Minangs, Palembangs, Dayaks, or mixed parentage and Chinese. The majority of males were Javanese $(54.2 \%)$, Sundanese $(20.3 \%)$, and Betawis (11.8\%).

\section{CT assessment}

The BMC were assessed with a Somatom-CR CTScanner (Siemens AG, Erlangen, Germany) at the Radiology Department of the St. Carolus Hospital in Jakarta. A single energy mode of $125 \mathrm{kV}$ was used. An axial section through the center of the L1, L2, and L3 vertebral bodies was made, with a scan time of 7 seconds at $670 \mathrm{mAS}$. Each section was $4 \mathrm{~mm}$ thick. The subject was supine with a calibration phantom composed of water and $200 \mathrm{mg} / \mathrm{ml} \mathrm{Ca} \mathrm{Hydroxyapatite}$ (standard Siemens reference) positioned underneath the lumbar vertebrae. Measurements were made for both trabecular and cortical bones.

Analysis was limited to the BMC of trabecular bone. 


\section{Data analysis}

The BMC was reported as mean and standard deviation (SD) values in boxplot and line graphs for each male and female age group.

Linear regression analysis was applied to estimate the changes of average bone mineral content with age both in males and females. ${ }^{13,14}$

The estimated values were presented along with a $95 \%$ confidence interval or 2 standard errors in graph and tables. Linear regression assumptions were made and the accuracy of the regression model evaluated with linear, quadratic, cubic, and double-breakpoint models. Data management and analysis used the SPSS computer software for statistics. ${ }^{15}$

Several regression models were evaluated before selecting the right model that precisely describes the pattern of changes in BMC with age, both in the female and male subjects. The BMC was described as $\mathrm{y}$ and the age in years as $\mathrm{x}$. The regression models were :

- simple linear regression model : $y=a+b x$

- quadratic linear regression model : $y=a+b x+c x^{2}$

- cubic linear regression model $\quad: \mathrm{y}=\mathrm{a}+\mathrm{bx}+\mathrm{cx}^{2}+\mathrm{dx}^{3}$

- double-breakpoint linear regression model :

$$
\begin{array}{ll}
y=a_{1}+b_{1} x & \text { for } x<x b_{1} \\
y=a_{2}+b_{2} x & \text { for } x b_{1} \leq x \leq x b_{2} \\
y=a_{3}+b_{3} x & \text { for } x>x b_{2}
\end{array}
$$

The slope and intercept on the simple, quadratic, and cubic models were estimated with the least squares method. The point of intersection is the point where the regression line changes in slope. It was determined by evaluating the change in mean values of 5-year-interval age groups.

\section{RESULTS}

Table 2 shows the mean and standard deviation of $\mathrm{BMC}$ values in $\mathrm{mg} / \mathrm{ml}$ for both men and women in various age groups. There was an increased reduction in both males and females over the age of 60 , the reduction was more pronounced in females.

Table 2. BMC of male and female in various age groups

\begin{tabular}{lrrrr}
\hline & \multicolumn{2}{c}{ female } & \multicolumn{2}{c}{ male } \\
Age group & mean & SD & mean & SD \\
\hline $20-30$ & 168.03 & 21.36 & 183.59 & 16.29 \\
$31-40$ & 164.19 & 25.07 & 156.76 & 34.43 \\
$41-50$ & 156.32 & 27.62 & 154.19 & 35.08 \\
$51-60$ & 121.45 & 51.45 & 122.13 & 26.85 \\
$61>$ & 78.51 & 31.61 & 87.76 & 8.79 \\
\hline Total & 152.11 & 39.02 & 144.52 & 40.28 \\
\hline
\end{tabular}

Figure $1 \mathrm{a}$ and $1 \mathrm{~b}$ shows the distribution of median and mode values for BMC of both males and females of various age groups. There was a marked decrease in median values beginning from the $50-60$ age group. The decrease was more pronounced in females.

The results of linear regression analysis showed a consistent decline in BMC with age, both in males and females. Theoretically, the rate of decline in the females should accelerate at a certain age, due to changes in the estrogen pattern which affects BMC. A precise regression model needs to be applied which will reflect the true changes.

No improvement in causative information was gained by using the cubic, quadratic, or double-breakpoint regression models in the male group. This meant that, in the male group, the linear regression model was sufficiently accurate in revealing information on BMC change with age.

In the female group, the quadratic regression model ( $\left.\mathrm{R}^{2}=0.5167\right)$ was more exact than the linear regression model $\left(\mathrm{R}^{2}=0.4247\right)$ in interpreting BMC changes with age. But compared to the quadratic model, the cubic regression model $\left(\mathrm{R}^{2}=0.5171\right)$ was slightly better.

The double-breakpoint linear regression model showed the following result :

\begin{tabular}{lc|ccc}
\hline \multicolumn{2}{c|}{ Age (years) } & \multicolumn{3}{c}{$\mathrm{mg} / \mathrm{ml}$} \\
B1 & B2 & Slope 1 & Slope 2 & Slope 3 \\
\hline 55 & 60 & -0.594 & -8.8 & -3.95 \\
\hline
\end{tabular}

This model showed a $-0.594 \mathrm{mg} / \mathrm{ml}$ reduction in BMC each year up to the age of 55. Then an accelerated reduction of $-8.8 \mathrm{mg} / \mathrm{ml}$ per year until the age of 60 . The rate of reduction decreased somewhat after the age of 60 . This is clearly shown in figure 2 .

\section{DISCUSSION}

The average $\mathrm{BMC}$ of male and female Indonesians, with ages ranging from 20 to 75 , was studied. The subjects were selected from a sample population of Program Jaminan Pemeliharaan Kesehatan members, a health plan of the St. Carolus Hospital.

Not all ethnic groups in Indonesia were represented but the majority was well represented.

The population in this study is not a true representation of the entire Indonesian population, since the sample was specified and restricted to members of the health plan. Therefore, the results of this study does not necessarily reflect the true values of the entire population. But if the sample can be considered as reflecting the general, healthy, Indonesian population, then the values can be regarded as reference values of average $\mathrm{BMC}$ of male and female Indonesians of various ages. 


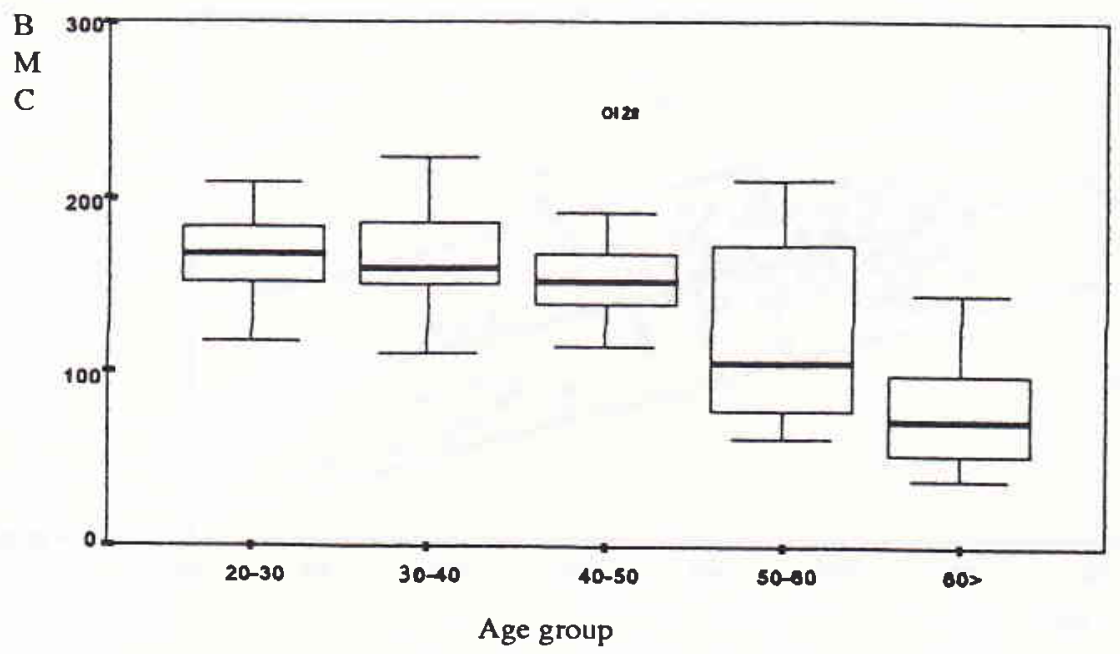

Figure la. BMC of females in various age groups

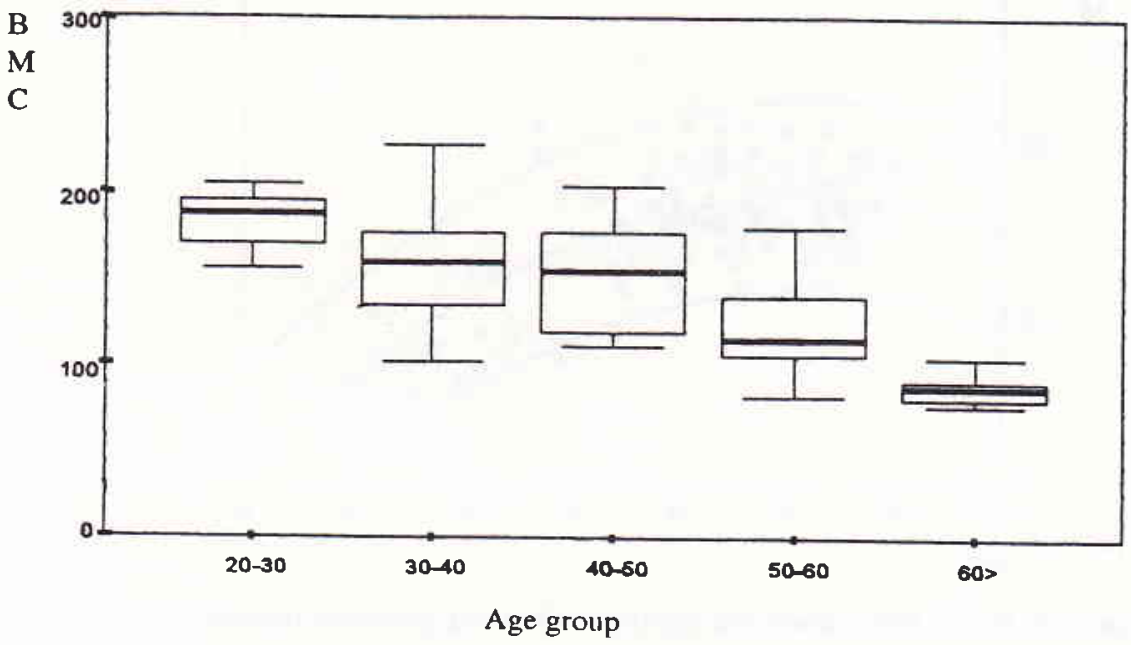

Figure Ib. BMC of males in various age groups

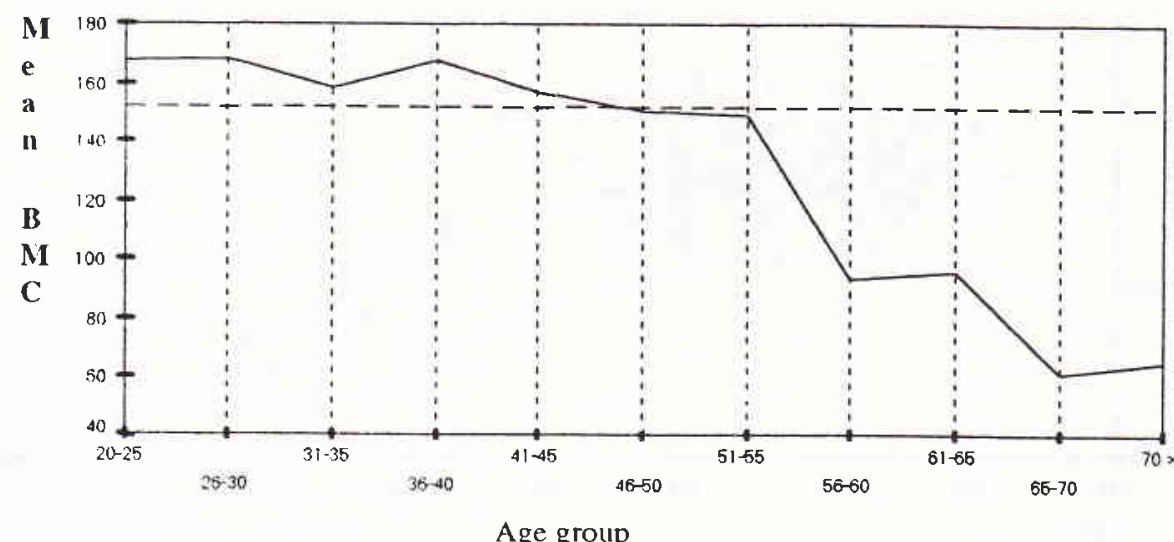

Figure 2. Average BMC in females of various age groups 


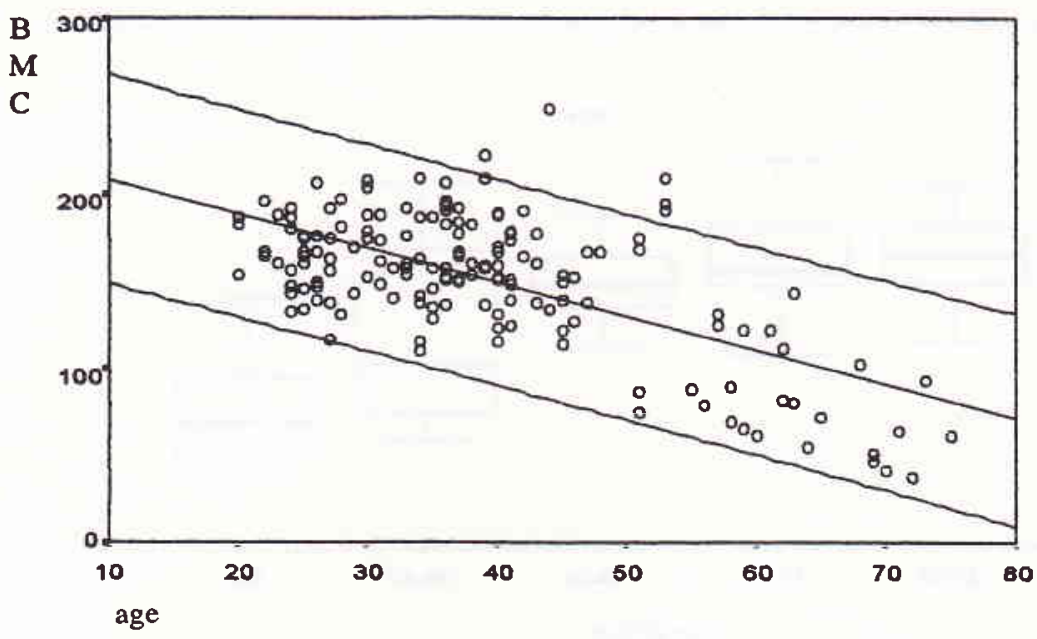

$R \otimes q=0.4247$

Figure $3 a$. Plot of BMC values and age in females using linear regression model

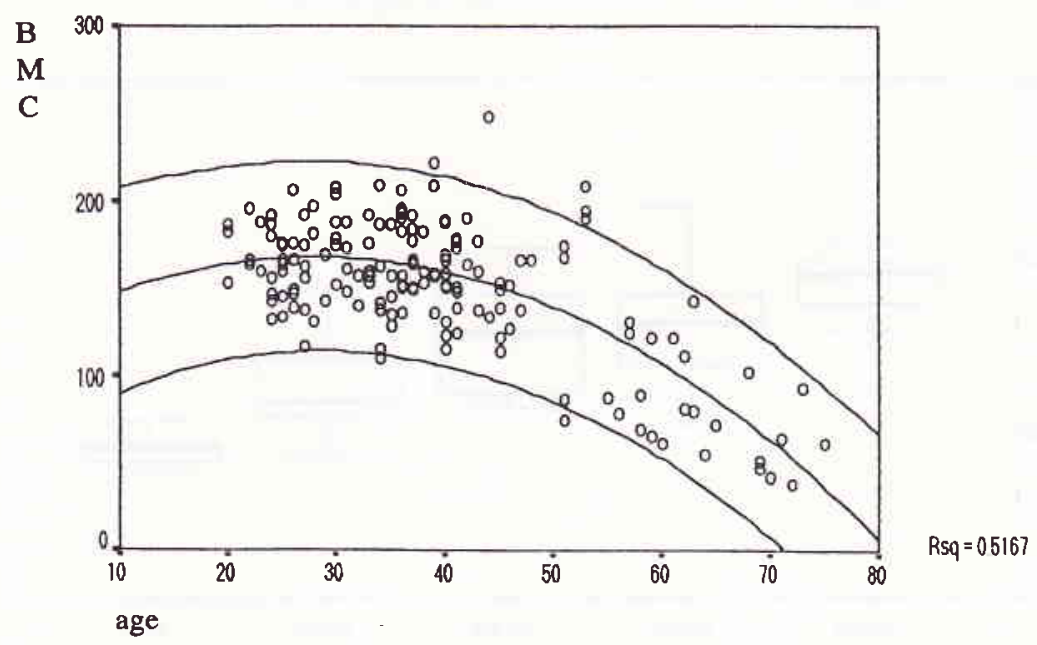

Figure $3 b$. Plot of BMC values and age in females using quadratic regression model

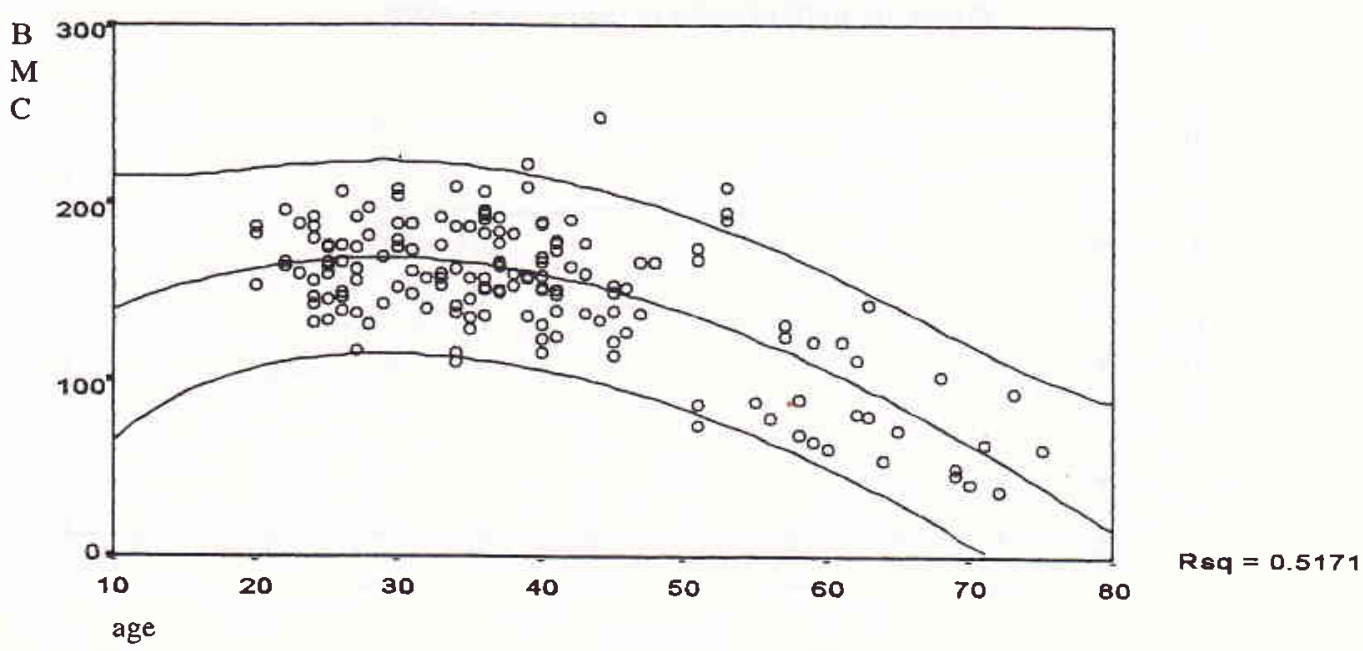

Figure 3c. Plot of BMC values and age in females using cubic regression model 


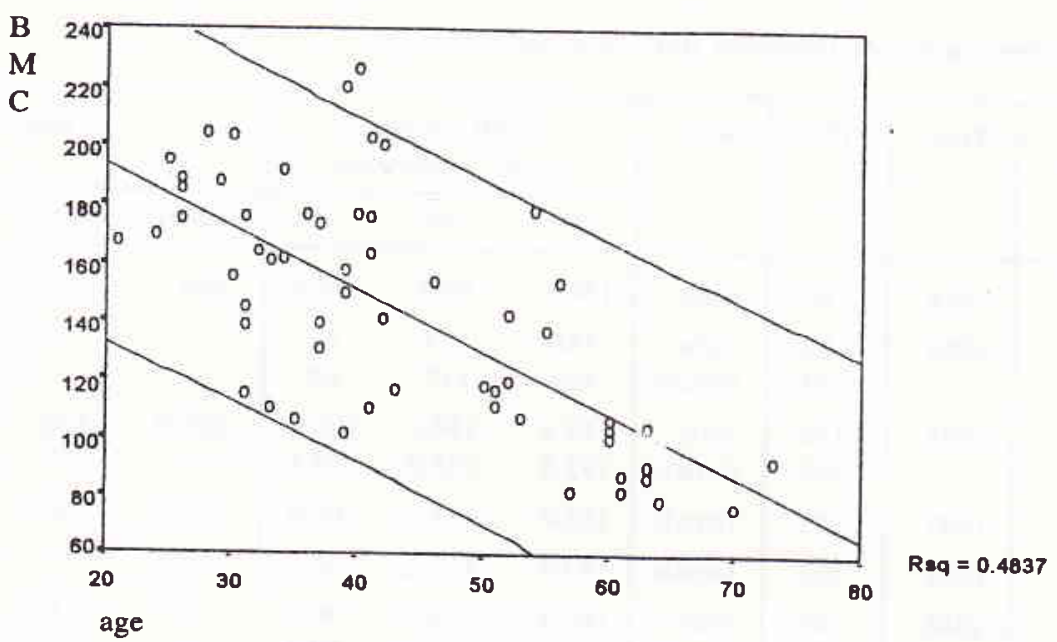

Figure 4a. Plot of BMC values and age in males using linear regression model

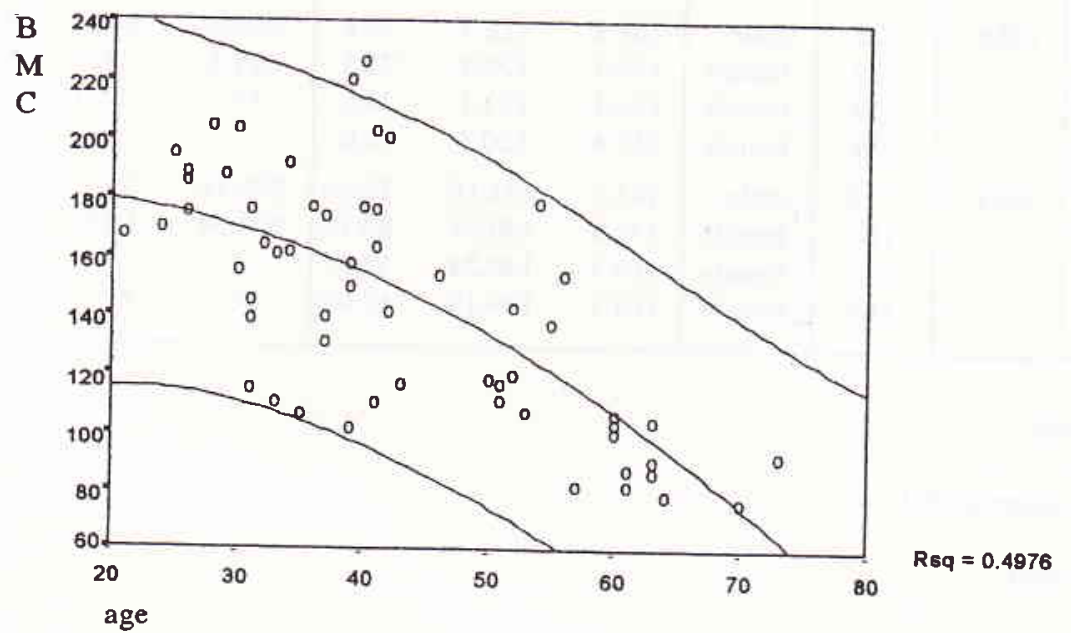

Figure 4b. Plot of BMC values and age in males using quadratic regression model

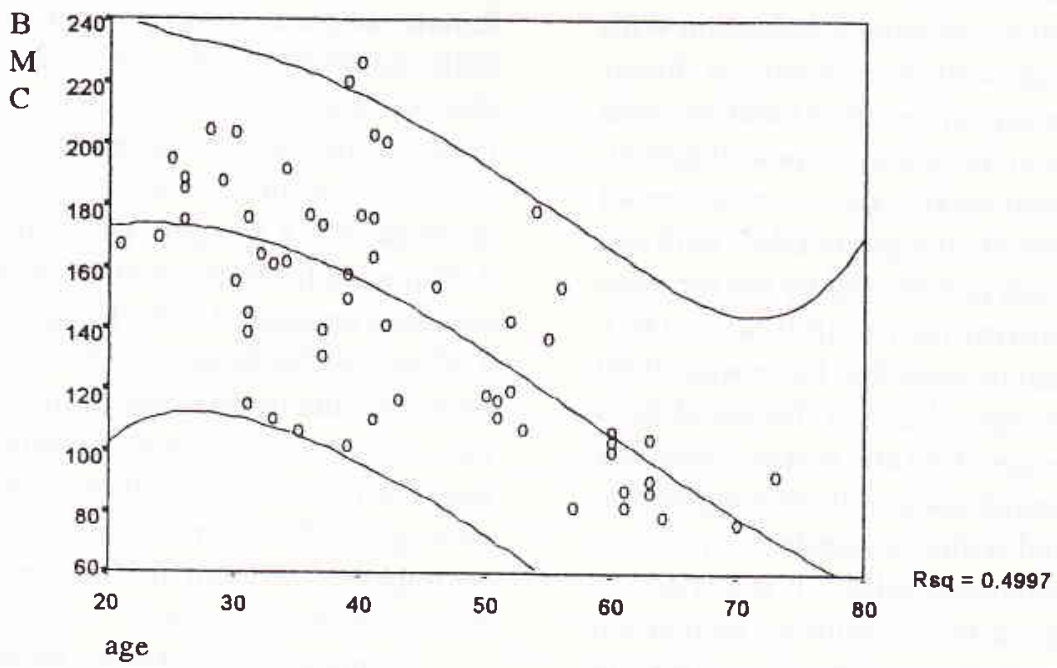

Figure 4c. Plot of BMC values and age in males using cubic regression model. 
Table 3. Comparison of reference data on trabecular BMC from various studies

\begin{tabular}{|c|c|c|c|c|c|c|c|c|c|c|}
\hline \multirow[t]{2}{*}{ Authors } & \multirow[t]{2}{*}{ Year } & \multirow[t]{2}{*}{$(\mathrm{N})$} & \multirow[t]{2}{*}{ Sex } & \multicolumn{3}{|c|}{$\begin{array}{l}\mathrm{BMC}(\mathrm{mg} / \mathrm{ml}) \\
\text { at age parameters }\end{array}$} & \multicolumn{4}{|c|}{ Regression } \\
\hline & & & & 25 & 50 & 75 & intercept & Slope & SE & r \\
\hline Meier et al & 1984 & 62 & male & 154.6 & 92.3 & 65.6 & 199.1 & -1.78 & - & -0.72 \\
\hline Laval-Jeantet et al & 1984 & $\begin{array}{r}98 \\
143\end{array}$ & $\begin{array}{l}\text { male } \\
\text { female }\end{array}$ & $\begin{array}{l}146 \\
159\end{array}$ & $\begin{array}{l}113 \\
117\end{array}$ & $\begin{array}{l}69 \\
65\end{array}$ & - & - & - & - \\
\hline Cann et al & 1985 & $\begin{array}{l}120 \\
203\end{array}$ & $\begin{array}{l}\text { male } \\
\text { female }\end{array}$ & $\begin{array}{l}184.4 \\
172.0\end{array}$ & $\begin{array}{l}144.1 \\
138.0\end{array}$ & $\begin{array}{r}103.9 \\
76.4\end{array}$ & $\begin{array}{c}224.6 \\
\star \star\end{array}$ & $\begin{array}{c}-1.61 \\
\star \star\end{array}$ & $\begin{array}{l}27.7 \\
30.8\end{array}$ & -0.69 \\
\hline Pacitici et al & 1987 & 153 & female & 168.4 & 117.1 & 65.9 & 219.6 & -2.05 & 25.0 & -0.67 \\
\hline Montag et al & 1988 & 203 & female & 147.5 & 115.1 & 60.0 & ** & $\star *$ & 20 & - \\
\hline Compston et al & 1988 & $\begin{array}{l}66 \\
63\end{array}$ & $\begin{array}{l}\text { male } \\
\text { female }\end{array}$ & $\begin{array}{l}161.5 \\
163.8\end{array}$ & $\begin{array}{l}126.0 \\
116.5\end{array}$ & $\begin{array}{l}90.5 \\
69.3\end{array}$ & $\begin{array}{l}197 \\
211\end{array}$ & $\begin{array}{l}-1.42 \\
-1.89\end{array}$ & - & $\begin{array}{l}-0.62 \\
-0.81\end{array}$ \\
\hline Block et al & 1988 & $\begin{array}{l}538 \\
538\end{array}$ & $\begin{array}{l}\text { female } \\
\text { female }\end{array}$ & $\begin{array}{l}181.5 \\
165.0\end{array}$ & $\begin{array}{l}131.0 \\
130.5\end{array}$ & $\begin{array}{l}80.5 \\
74.0\end{array}$ & $\begin{array}{c}232.0 \\
\star \star\end{array}$ & $\begin{array}{c}-2.02 \\
\star \star\end{array}$ & $\begin{array}{l}26.5 \\
26.0\end{array}$ & $\begin{array}{l}-0.67 \\
-0.69\end{array}$ \\
\hline Kalender et al & 1988 & $\begin{array}{l}135 \\
139 \\
139 \\
139\end{array}$ & $\begin{array}{l}\text { male } \\
\text { female } \\
\text { female } \\
\text { female }\end{array}$ & $\begin{array}{l}164.8 \\
166.3 \\
161.4 \\
157.8\end{array}$ & $\begin{array}{l}122.3 \\
120.8 \\
123.1 \\
120.3\end{array}$ & $\begin{array}{l}79.8 \\
75.3 \\
72.6 \\
76.0\end{array}$ & $\begin{array}{c}207.3 \\
211.8 \\
\star \star \\
+\end{array}$ & $\begin{array}{c}-1.70 \\
-1.82 \\
* \star \\
+\end{array}$ & $\begin{array}{l}26.3 \\
27.9 \\
27.6 \\
27.4\end{array}$ & $\begin{array}{l}-0.73 \\
-0.74 \\
-0.75 \\
-0.76\end{array}$ \\
\hline Own work & 1994 & $\begin{array}{r}59 \\
164 \\
164 \\
164\end{array}$ & $\begin{array}{l}\text { male } \\
\text { female } \\
\text { female } \\
\text { female }\end{array}$ & $\begin{array}{l}183.7 \\
179.3 \\
168.4 \\
168.2\end{array}$ & $\begin{array}{l}131.16 \\
130.04 \\
140.24 \\
139.19\end{array}$ & $\begin{array}{l}78.66 \\
80.79 \\
37.35 \\
41.09\end{array}$ & $\begin{array}{c}236.16 \\
228.54 \\
\star \\
\star \star\end{array}$ & $\begin{array}{c}-2.1 \\
-1.97 \\
\star \\
\star \star\end{array}$ & $\begin{array}{l}29.20 \\
29.69 \\
27.29 \\
27.37\end{array}$ & $\begin{array}{l}-0.70 \\
-0.65 \\
-0.72 \\
-0.72\end{array}$ \\
\hline
\end{tabular}

* quadratic regression model

** cubic regression model

+ double-breakpoint regressiom model

From : Europ J Radiol 9 (1989)

The regression analysis model used to describe the changes in BMC pattern showed a reduction with age. The male group showed a uniform, or linear reduction. The female group on the other hand, showed an accelerated reduction in the postmenopausal period.

The cubic regression model gave a more exact information on the pattern of changes in BMC with age in the female group, which is reflected by the increase in the regression determination indicator $\left(R^{2}\right)$. Through this model it can be seen that there was slight increase in BMC at the age of 20-30, followed by a slight decrease after the age of 40 and marked decrease after the age of 50. Although some authors suggest that a linear regression model within 2 standard errors can in practice be used as reference values, it is advised to apply the cubic regression model with an estimation area of 2 standard error as reference for BMC in women. The linear regression model can be applied to estimate the BMC of male subjects.
The double-breakpoint regression model of the female subjects, showed that BMC reduction was initially stable then followed by 2 accelerated reduction, after the age of 55 and 65 . This differs from the findings of Kalender for Europeans, where the accelerated reduction occured over the age of 40 and 56. The decrease was $8.8 \mathrm{mg} / \mathrm{ml}$ per year for those over 55 and $3.95 \mathrm{mg} / \mathrm{ml}$ for those over 65 in the female Indonesian subjects, compared to $3.21 \mathrm{mg} / \mathrm{ml}$ for those over 40 and $1.57 \mathrm{mg} / \mathrm{ml}$ for those over 56 in Europeans. ${ }^{7}$ This was probably due to differences in dietary patterns, physical activity, estrogen deficiency, or the use of postmenopausal supplementary drugs including estrogen. Further studies are needed on postmenopausal women in Indonesia, especially on the effects of those factors.

Comparisons between results of several studies can be seen in Table 3. In general, it can be noted that the pattern of change is the same. The rate of BMC 
reduction may differ according to the regression model employed, and if only subjects of perimenopausal age is used.

\section{CONCLUSIONS}

1. The rate of BMC reduction with age in the female subjects was not uniform, there was an accelerated reduction in the perimenopausal period.

2. The rate of BMC reduction with age in the male subjects was uniform.

3. Average $B M C$ values, based on the appropriate regression model, of both male and female subjects of various age groups can be considered as reference values for Indonesians.

4. The average BMC values of Indonesian males of various age groups and Indonesian females up to the age of 50 does not differ much from other studies; it was found to be different in Indonesian females over the age of 50 .

\section{SUGGESTIONS}

Future studies on osteoporosis should cover :

* BMC studies using a wider cross-sectional design on different population samples.

* Longitudinal or follow-up studies to determine the rate of natural BMC reduction in Indonesians.

* Cross-sectional or longitudinal studies to determine the BMC where the risk of fractures increases ( fracture threshold)

* Studies on the rate of BMC reduction of menopausal women and the effects of dietary patterns of calcium rich food, physical activity, supplementary estrogen and other factors.

\section{Acknowledgements}

The authors wish to thank Dr. A. Mariono, former Director of PK St.Carolus, The Board of Directors of PK St. Carolus, The Head of PJPK St. Carolus and his staff, the radiographers and technicians at the Radiology Department of PK St. Carolus, and the Chairman of Health Studies Centre of the Research Institute of the University of Indonesia.

\section{REFERENCES}

1. Riggs BL, Meltonn LJ. Involution osteoporosis, N Egl J Med. 1986;26:1676-86.

2. Lampmann LEH. Axial Skeletal CT densitometry, Proefschrift. Wetenschappelijke Uitgeverij Bunge - Utrecht, 1982.

3. Cann CE, Gennant HK, Kolb FO, Ettinger B. Quantitative CT for prediction of vertebral fracture risk. Bone 1985;6:1-7.

4. Compston JE, Evans WD, Crawley EO, Evans C. Bone mineral content in normal UK subjects. $\mathrm{Br} \mathrm{J}$ Radiol. 1988;61:631-6.

5. Gilsanz V, Gibbens DT, Roe TF, Carlson M. Vertebral bone density in children: Effect of Puberty. Radiology. 1986;166:847-50.

6. Pacifici R, Susman N, Carr PL, Birge S, Aviole LV. Singleand dual-energy tomographic analysis of spinal trabecular bone: a comparative study in normal annd osteoporotic women. JCEM. 1987;64:209-14.

7. Kalender WA, Felsenberg D, Louis O, Lopez P, Klotz E, Osteaux M, et al. Reference Values for Trabecular and Cortical Vertebral Bone Density in Single and Dual-Energy Quantitative Computed Tomography. Eur J Radiology. 1989;9:75-80.

8. Genant HK, Block JE, Steiger P, Gluer CC. Quantitative Computed Tomography in the Assessment of Osteoporosis In : Genant HK, editor. Osteoporosis Update 1987. Radiology Research and Education Foudation, California; 1987:49-71.

9. Pacifici R, Rupich R; Griffin M, Chines A, Susman M, Avioli LV. Dual Energy Radiography versus Quantitative Computer Tomography for the Diagnosis of Osteoporosis. JCEM. 1990;70:705-10.

10. Meier DE, Ortvoll ES, Johns JM. Market disparity between trabecular and Cortical bone loss with age in healthy men. Ann Intern Med. 1984;101:605-12.

11. Riggs BL, Wahner HW, Dunn WL, Mazess RB, Offord KP, Melton III LJ. Differential changes in bone mineral density of the appendicular and axial skeleton with aging-Relationship to Spinal Osteoporosis. J Clin Inves. 1981;67:328-35.

12. Wolf-Dieter Reinbold, Genant HK, Reiser UJ, Harris ST, Ettinger B. Bone mineral content in early menopausal and post-menopausal osteoporotic women; Comparison of measurement methods. Radiology 1986;160:469-78.

13. Draper NR, Smith H. Applied Regression Analysis, New York: Wiley, 1981.

14. Kleinbaum, Kupper, Muller. Applied Regression and Other Multivariable Methods. 2nd ed. Boston: PWS-Kent, 1988.

15. Norusis MJ, SPSS for windows User's Guide release 5.0, Chicago:SPSS,Inc, 1992. 